\title{
Nevus sebaceous in a child caused by pregnancy with an intrauterine device (IUD) in situ
}

\author{
Lise Bangsgaard Fensby, ${ }^{1}$ Anne-Kathrine Reus Carstens, ${ }^{1}$ Luit Penninga ${ }^{2}$
}

${ }^{1}$ Aarhus University, Aarhus C, Denmark

2llulissat Hospital, Ilulissat, Greenland

\section{Correspondence to} Dr Luit Penninga, LP@ctu.dk

Accepted 26 May 2016

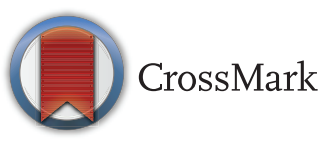

To cite: Fensby $L B$, Carstens A-KR, Penninga L. BMJ Case Rep Published online: [please include Day Month Year] doi:10.1136/ bcr-2016-215833

\section{DESCRIPTION}

Pregnancy with an intrauterine device (IUD) in situ occurs at a rate of 0.1 per 100 woman-years. ${ }^{1}$ Most frequently, the IUD is removed, because it may cause early abortion. Currently, an IUD in situ during pregnancy is not known to cause any other harm to the fetus. ${ }^{2}$

We present the case of a 10 -year-old boy who had been born after pregnancy with an IUD in situ. The pregnancy had otherwise been uneventful, and he was born after vaginal delivery. At birth, it was observed that the IUD was located behind the right ear of the infant. Since birth, he had suffered from an uncharacteristic skin mark behind his right ear, where the IUD had been located. The skin lesion itched and irritated and, at times, the boy experienced a worsening of the condition, with minor bleeding, exudation and infection. When worsening occurred, he received topical treatment with corticosteroids or antibiotics. At the age of 10 years, the lesion was $3 \mathrm{~cm}$ long and $4 \mathrm{~mm}$ wide (figure 1). At this point, surgical resection was offered, accepted and performed (figure 2). The postoperative phase was without complications. Pathological examination showed a nevus sebaceous, which is an epidermal hyperplasia, caused by growth of excess sebaceous glands. The nevus is often present at birth, and thought to come from a small defect in fetal ectoderm. ${ }^{3}$

The present case shows that pregnancy with an IUD in situ may cause skin lesions at the site where the IUD is located on the skin of the fetus. Surgical resection is the definitive treatment for these lesions, also because there is a small risk of malignant change after puberty.

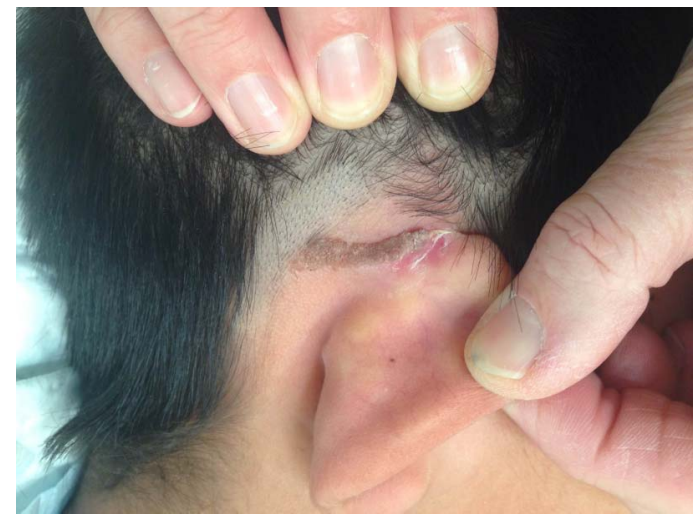

Figure 1 Nevus sebaceous behind the right ear.

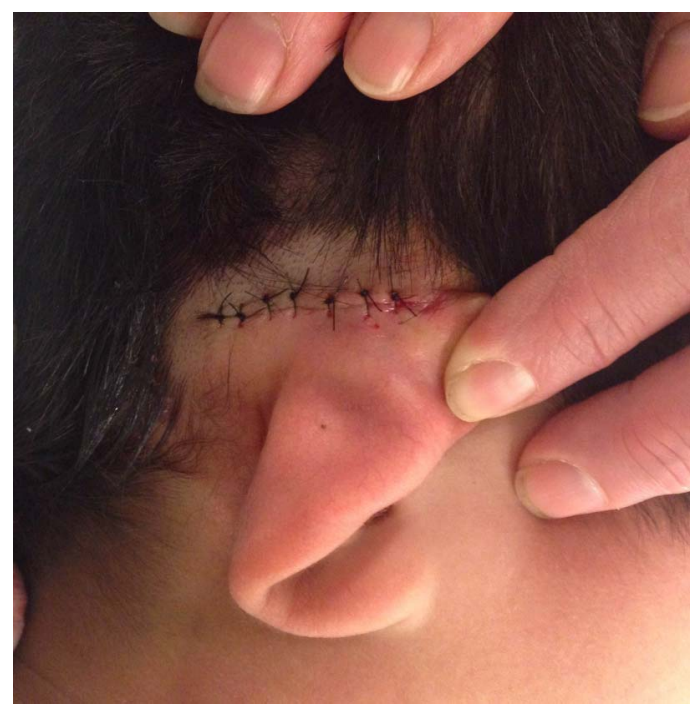

Figure 2 The nevus sebaceous was surgically resected.

\section{Learning points}

Pregnancy with an intrauterine device (IUD) in situ may cause skin lesions at the site where the IUD is located on the skin of the fetus.

- When a woman has had an IUD in situ during pregnancy, it is important to examine the child for any skin changes.

- Surgical resection is the definitive treatment for nevus sebaceous, also because there is a small risk of malignant change after puberty.

Competing interests None declared.

Patient consent Obtained.

Provenance and peer review Not commissioned; externally pee reviewed.

\section{REFERENCES}

1 Stanford JB, Mikolajczyk RT. Mechanisms of action of intrauterine devices. Update and estimation of postfertilization effects. Am J Obstet Gynecol 2002;187:1699-708.

2 Brahmi D, Steenland MW, Renner RM, et al. Pregnancy outcomes with an IUD in situ: a systematic review. Contraception 2012;85:131.

3 Eisen DB, Michael DJ. Sebaceous lesions and their associated syndromes: part I. J Am Acad Dermatol 2009;61:549. 


\section{Images in...}

Copyright 2016 BMJ Publishing Group. All rights reserved. For permission to reuse any of this content visit http://group.bmj.com/group/rights-licensing/permissions.

BMJ Case Report Fellows may re-use this article for personal use and teaching without any further permission.

Become a Fellow of BMJ Case Reports today and you can:

- Submit as many cases as you like

- Enjoy fast sympathetic peer review and rapid publication of accepted articles

- Access all the published articles

- Re-use any of the published material for personal use and teaching without further permission

For information on Institutional Fellowships contact consortiasales@bmjgroup.com

Visit casereports.bmj.com for more articles like this and to become a Fellow 